\title{
Engineering Properties of Cement CONTAINING POND ASH
}

\author{
Milind P. Bhamare ${ }^{1}$, Yogesh N. Bafna ${ }^{2}$, Arun K. Dwivedi ${ }^{3}$
}

\begin{abstract}
A thermal power plants converts energy rich fuel into electricity and heat. Coal produced electricity takes about $80 \%$ of the total power generated in India. The coal based power plant generates a huge amount of ash. The generated ash contains about 20 percent Pond ash and 80 percent fly ash of the total ash generated. Fly ash is been recycled as an alternative to cement while pond ash is being disposed off. Pond ash requires huge area, water and energy to dispose itself off so recycling of the pond ash is indeed required. This paper concentrates on utilization of pond ash as a cement replacement.
\end{abstract}

\section{Introduction}

A thermal power plants converts energy rich fuel into electricity and heat. The fuel includes coal, natural gases, petroleum products, agriculture waste and domestic trash/waste, landfill gas and biogas etc. Coal and liginte accounts for about $57 \%$ of India's installed capacity of power generation. Coal produced electricity takes about $80 \%$ of the total power generated in India. The Indian power plant uses coal like Gondwana coal; it has low calorific value and high ash content which requires $0.7 \mathrm{~kg}$ of coal to generate a $1 \mathrm{kwh}$ of electricity.

The coal based power plant generates a huge amount of ash. In India, it is about 170 MT for the year 2011-12 and is expected to be above 600MT for the year 2031-32. The generated ash contains about 20 percent Pond ash and 80 percent fly ash of the total ash generated. Fly ash is been recycled as an alternative to cement while pond ash is being disposed off. The disposal of large quantity of pond ash requires huge area of land, water and energy. If not managed well becomes a health hazard and damages the environment. With increased power consumption the generation of coal ash has been growing annually and need for additional disposal sites has become urgent. So recycling pond ash might be able to sort out the above mentioned issues. This paper addresses the issues pertaining to the change in engineering properties of the cement containing pond ash.

\subsection{MATERIALS-}

\section{Experimental Work}

Experimentations have been on 53 grade OPC cement to find out its physical and chemical properties. The physical and chemical properties of OPC cement used for the research work are shown in the Table 1 and 2. Pond ash used for the cement replacement is collected from the thermal power plant situated at Deepnagar, Bhusawal, Maharashtra. Quartzanium TM Sand (standard sand) used as fine aggregate, for research work. Properties of pond ash and standard sand are given in Table 3 and 4. Figure 1 shows the grain size distribution of pond ash. It is observed that 66 percent of Total weight of the pond ash is smaller than $0.075 \mathrm{~mm}$. Fineness modulus is 1.656

Table 1. Chemical Characteristics of Cement.

\begin{tabular}{|l|c|c|c|c|c|c|}
\hline \multicolumn{1}{|c|}{$\begin{array}{c}\text { Type of } \\
\text { Cement }\end{array}$} & $\begin{array}{c}\text { Lime } \\
\text { Saturation } \\
\text { Factor }(\%)\end{array}$ & $\begin{array}{c}\text { Alumina } \\
\text { Iron Ratio } \\
(\%) \text { Min. }\end{array}$ & $\begin{array}{c}\text { Insoluble } \\
\text { Residue } \\
(\%) \text { Max. }\end{array}$ & $\begin{array}{c}\text { Magnesia } \\
(\%) \text { Max. }\end{array}$ & $\begin{array}{c}\text { Sulphuric } \\
\text { Anhydride }\end{array}$ & $\begin{array}{c}\text { Loss on } \\
\text { Ignition } \\
(\%) \text { Max. }\end{array}$ \\
\hline $\begin{array}{l}\text { OPC }(53 \text { Grade) } \\
\text { IS 12269- } \\
1987)\end{array}$ & $\begin{array}{c}0.8 \text { Min., } \\
1.02 \text { Max. }\end{array}$ & 0.66 & 2 & 6 & $2.5 \%$ Max. & 4 \\
\hline
\end{tabular}

Table 2 "Physical Characteristics of Cement."

\begin{tabular}{|l|c|c|c|c|c|c|}
\hline \multirow{2}{*}{$\begin{array}{l}\text { Type of } \\
\text { Cement }\end{array}$} & \multirow{2}{*}{ Fineness \% } & \multirow{2}{*}{$\begin{array}{c}\text { Soundness } \\
(\mathrm{mm})\end{array}$} & \multicolumn{2}{|c|}{ Setting Time } & \multicolumn{2}{c|}{ Compressive Strength } \\
\cline { 4 - 7 } & & $\begin{array}{l}\text { Initial } \\
(\mathrm{mins})\end{array}$ & $\begin{array}{l}\text { Final } \\
(\mathrm{mins})\end{array}$ & $\begin{array}{c}3 \text { Days } \\
\mathrm{N} / \mathrm{mm}^{2}\end{array}$ & $\begin{array}{c}7 \text { Days } \\
\mathrm{N} / \mathrm{mm}^{2}\end{array}$ \\
\hline $\begin{array}{l}\mathrm{OPC}_{(53 \mathrm{Grade})} \\
\left(\begin{array}{l}\text { IS 12269- } \\
1987)\end{array}\right.\end{array}$ & $2.7 \%$ & $2.5 \mathrm{~mm}$ & 52 & 290 & 27.5 & 37.25 \\
\hline
\end{tabular}


Table 3 "Physical and Chemical Characteristics of Standard sand."

\begin{tabular}{|c|c|}
\hline Properties & \multicolumn{1}{|c|}{$\begin{array}{c}\text { Quartzanium TM Sand } \\
\text { (Standard Sand) }\end{array}$} \\
\hline Color & Whitish \\
\hline Ppecific Gravity & 2.65 \\
\hline W. Absorption in 24 hours & $0.30 \%$ \\
\hline Shape of Grains & Sub Angular \\
\hline $\mathrm{SiO}_{2}$ & \\
\hline $\mathrm{Al}_{2} \mathrm{O}_{3}$ & $99.42 \%$ \\
\hline $\mathrm{Fe}_{2} \mathrm{O}_{3}$ & $0.18 \%$ \\
\hline $\mathrm{CaO}$ & $0.02 \%$ \\
\hline Loss on Ignition & - \\
\hline
\end{tabular}

Table 4 Physical Properties of Pond Ash

\begin{tabular}{|c|c|}
\hline Properties & Pond Ash \\
\hline Color & Physical Properties \\
\hline Specific Gravity & Whitish grey \\
\hline W. Absorption in 24 hours & 2.153 \\
\hline
\end{tabular}

Fig. 1 particle size distribution curve f Pond ash

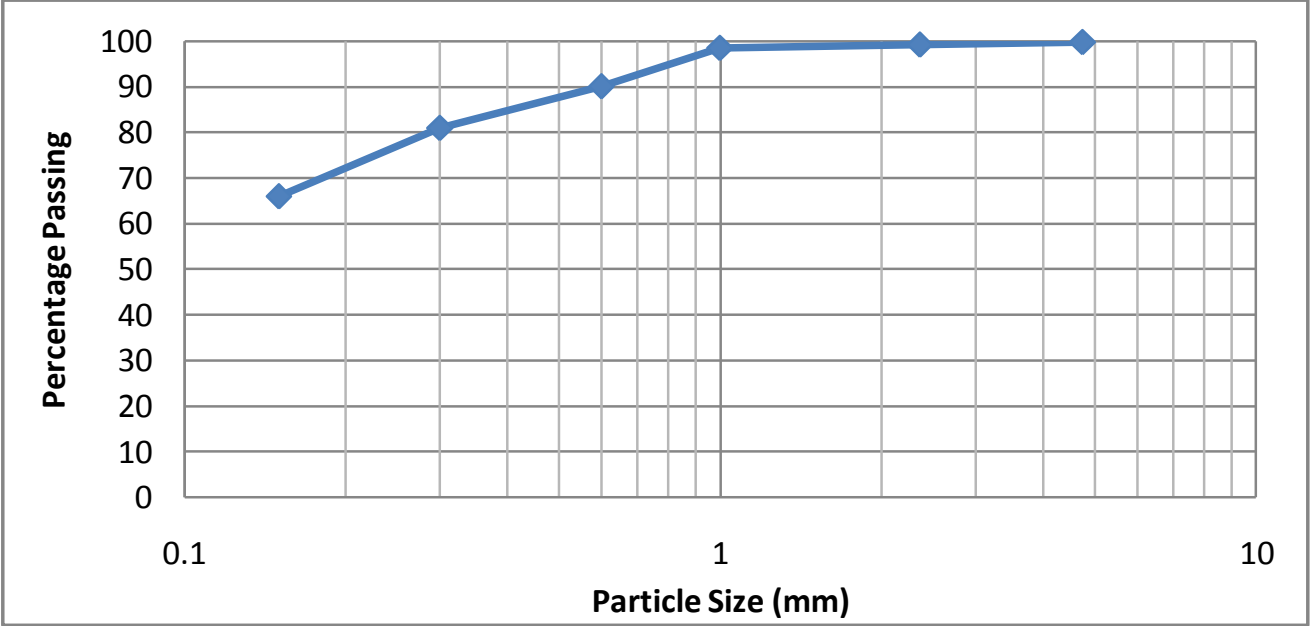

\subsection{Mix Proportions}

As a replacement of cement, pond ash is mix in different percentage. The percentage and mix proportions are given in the Table 5 .

Table 5 Cement labels and mix proportions

\begin{tabular}{|c|c|c|c|c|c|}
\hline \multirow{2}{*}{$\begin{array}{l}\text { Sr. } \\
\text { No }\end{array}$} & \multirow[b]{2}{*}{ Description and Label } & Mix proportion & \multicolumn{3}{|c|}{ Quantity of material (kg) } \\
\hline & & C:PA:S & Cement & $\begin{array}{l}\text { Pond } \\
\text { ash }\end{array}$ & Sand \\
\hline \multirow{2}{*}{1} & \multirow{2}{*}{$\begin{array}{l}\text { OPC including } 0.0 \% \text { of pond ash by mass of } \\
\text { cement as replacement of cement (OPC) }\end{array}$} & $\mathrm{OPC}$ & \multirow{2}{*}{2.22} & \multirow{2}{*}{0} & \multirow{2}{*}{6.66} \\
\hline & & 1:00:03 & & & \\
\hline \multirow{2}{*}{2} & \multirow{2}{*}{$\begin{array}{l}\text { OPC including } 2.5 \% \text { of pond ash by mass of } \\
\text { cement as replacement of cement (M 1) }\end{array}$} & M 1 & \multirow{2}{*}{2.165} & \multirow{2}{*}{0.051} & \multirow{2}{*}{6.66} \\
\hline & & $0.975: 0.025: 3$ & & & \\
\hline 3 & OPC including $5.0 \%$ of pond ash by mass of & M 2 & 2.109 & 0.111 & 6.66 \\
\hline
\end{tabular}




\begin{tabular}{|c|c|c|c|c|c|}
\hline & cement as replacement of cement (M 2) & 0.950:0.05:3 & & & \\
\hline \multirow{2}{*}{4} & \multirow{2}{*}{$\begin{array}{l}\text { OPC including } 7.5 \% \text { of pond ash by mass of } \\
\text { cement as replacement of cement (M 3) }\end{array}$} & M3 & \multirow{2}{*}{2.054} & \multirow{2}{*}{0.167} & \multirow{2}{*}{6.66} \\
\hline & & 0.925:0.075:3 & & & \\
\hline \multirow{2}{*}{5} & \multirow{2}{*}{$\begin{array}{l}\text { OPC including } 10.0 \% \text { of pond ash by mass of } \\
\text { cement as replacement of cement (M 4) }\end{array}$} & M 4 & \multirow{2}{*}{1.998} & \multirow{2}{*}{0.222} & \multirow{2}{*}{6.66} \\
\hline & & $0.90: 0.1: 3$ & & & \\
\hline \multirow{2}{*}{6} & \multirow{2}{*}{$\begin{array}{l}\text { OPC including } 12.5 \% \text { of pond ash by mass of } \\
\text { cement as replacement of cement (M 5) }\end{array}$} & M 5 & \multirow{2}{*}{1.943} & \multirow{2}{*}{0.278} & \multirow{2}{*}{6.66} \\
\hline & & $0.875: 0.125: 3$ & & & \\
\hline \multirow{2}{*}{7} & \multirow{2}{*}{$\begin{array}{l}\text { OPC including } 15.0 \% \text { of pond ash by mass of } \\
\text { cement as replacement of cement ((M 6)) }\end{array}$} & M 6 & \multirow{2}{*}{1.887} & \multirow{2}{*}{0.333} & \multirow{2}{*}{6.66} \\
\hline & & $0.85: 0.15: 3$ & & & \\
\hline \multirow{2}{*}{8} & \multirow{2}{*}{$\begin{array}{l}\text { OPC including } 17.5 \% \text { of pond ash by mass of } \\
\text { cement as replacement of cement ((M 7) }\end{array}$} & M 7 & \multirow{2}{*}{1.832} & \multirow{2}{*}{0.389} & \multirow{2}{*}{6.66} \\
\hline & & 0.825:0.175:3 & & & \\
\hline \multirow{2}{*}{9} & \multirow{2}{*}{$\begin{array}{l}\text { OPC including } 20.0 \% \text { of pond ash by mass of } \\
\text { cement as replacement of cement (M 8) }\end{array}$} & M 8 & \multirow{2}{*}{1.776} & \multirow{2}{*}{0.444} & \multirow{2}{*}{6.66} \\
\hline & & $0.8: 0.2: 3$ & & & \\
\hline \multirow{2}{*}{10} & \multirow{2}{*}{$\begin{array}{l}\text { OPC including } 22.5 \% \text { of pond ash by mass of } \\
\text { cement as replacement of cement (M 9) }\end{array}$} & M 9 & \multirow{2}{*}{1.720} & \multirow{2}{*}{0.500} & \multirow{2}{*}{6.66} \\
\hline & & $0.775: 0.225: 3$ & & & \\
\hline
\end{tabular}

\subsection{Test methods}

Materials used in this research work are an OPC cement, pond ash and fine aggregate, Materials are tested as per Indian standard and mention in the Table 6 below.

Table 6 Standard utilized for testing

\begin{tabular}{|l|l|}
\hline Test Method & Related Standard \\
\hline Normal Consistency & I.S.4031- (Part 4) 1988 \\
Setting Time & I.S.4031-(Part 5) 1988 \\
La Chatelier & IS : 4031-(Part 3) 1988 \\
\hline \multicolumn{2}{|l|}{ Tests Performed on Cement Mortar } \\
\hline Compressive Strength & IS : 4031-(Part 6) 1988 \\
\hline
\end{tabular}

\section{Test results and discussions}

\subsection{Analysis of the properties of cement}

\subsubsection{Normal consistency of cement- I.S.4031- (Part 4) 1988}

The test results are shown in Table 7. Due to the porous nature of the pond ash particles, requires more water to make a plastic cement paste compare to ordinary Portland cement. It is observed that an amount of water required to make a plastic cement paste goes on increasing with the percentage content of the pond ash in cement.

Table 7. Normal Consistency Result of Cement Pastes

\begin{tabular}{|c|c|c|c|}
\hline \multirow{2}{*}{ Cement } & \multirow{2}{*}{ \% of Pond Ash } & \multicolumn{2}{|c|}{$\begin{array}{c}\text { Required Amount of water for } \\
\text { Normal Consistency }\end{array}$} \\
\cline { 2 - 4 } & & $\%$ & gm \\
\hline OPC & 0.0 & 30.0 & 90.0 \\
\hline M1 & 2.5 & 31.8 & 95.4 \\
\hline M2 & 5.0 & 32.9 & 98.7 \\
\hline M3 & 7.5 & 33.6 & 100.8 \\
\hline M4 & 10.0 & 34.7 & 104.1 \\
\hline M5 & 12.5 & 35.8 & 107.4 \\
\hline M6 & 15.0 & 37.9 & 113.7 \\
\hline M7 & 17.5 & 39.4 & 118.2 \\
\hline M8 & 20.0 & 40.8 & 122.4 \\
\hline M9 & 22.5 & 42.1 & 126.3 \\
\hline
\end{tabular}




\subsubsection{Setting Time}

For ease of construction the initial setting must not be too short and final setting must not be too long. Table 8 shows the initial and final setting time values for ordinary Portland cement containing different percentage of pond ash. Initial and final setting time increases with the increase in the percentage of pond ash content in the cement. Increased time seen due to the less pozzolanic properties of pond ash.

Table 8 Setting Time of Cement

\begin{tabular}{|c|c|c|c|}
\hline Cement & $\begin{array}{c}\text { Percentage } \\
\text { of Pond Ash }\end{array}$ & $\begin{array}{c}\text { Initial Setting Time } \\
\text { (min.) }\end{array}$ & $\begin{array}{c}\text { Final Setting Time } \\
\text { (min.) }\end{array}$ \\
\hline OPC & 0 & 52 & 290 \\
\hline M1 & 2.5 & 55 & 302 \\
\hline M2 & 5 & 60 & 308 \\
\hline M3 & 7.5 & 68 & 319 \\
\hline M4 & 10 & 73 & 328 \\
\hline M5 & 12.5 & 78 & 345 \\
\hline M6 & 15 & 84 & 357 \\
\hline M7 & 17.5 & 88 & 373 \\
\hline M8 & 20 & 94 & 386 \\
\hline M9 & 22.5 & 102 & 395 \\
\hline
\end{tabular}

\subsubsection{Volume Expansion}

The test was conducted on 10 samples containing 0 to $22.5 \%$ of pond ash using le Chateliers soundness test. This test only takes into account $\mathrm{CaO}$. Hydration product has larger volume than that of free time and finally gives rise to cracks. Thus, partly replaced pond ash give advantages volume expansion results due to lower free time value in cement paste.

Table 9 Soundness test of Cement

(Values are near to $0.5 \mathrm{~mm}$ )

\begin{tabular}{|c|c|c|}
\hline Cement & \% of Pond Ash & Change in distance $(\mathrm{mm})$ \\
\hline OPC & 0 & 2.5 \\
\hline M1 & 2.5 & 3.0 \\
\hline M2 & 5 & 2.5 \\
\hline M3 & 7.5 & 2.5 \\
\hline M4 & 10 & 2.0 \\
\hline M5 & 12.5 & 2.0 \\
\hline M6 & 15 & 2.0 \\
\hline M7 & 17.5 & 2.0 \\
\hline M8 & 20 & 1.5 \\
\hline M9 & 22.5 & 1.5 \\
\hline
\end{tabular}

\subsubsection{Compressive Strength of Cement}

The compressive strength of cement decreases with increase by the content of percentage pond ash. The growing content of pond ash is responsible for decrease in the compressive strength of cement. A mix of cement \& pond ash has less compressive strength as compared to the OPC as pond ash contains both fine as well as non reactive large particle due to which it has less pozzolanic property.

Graph 2 Compressive strength of cement 


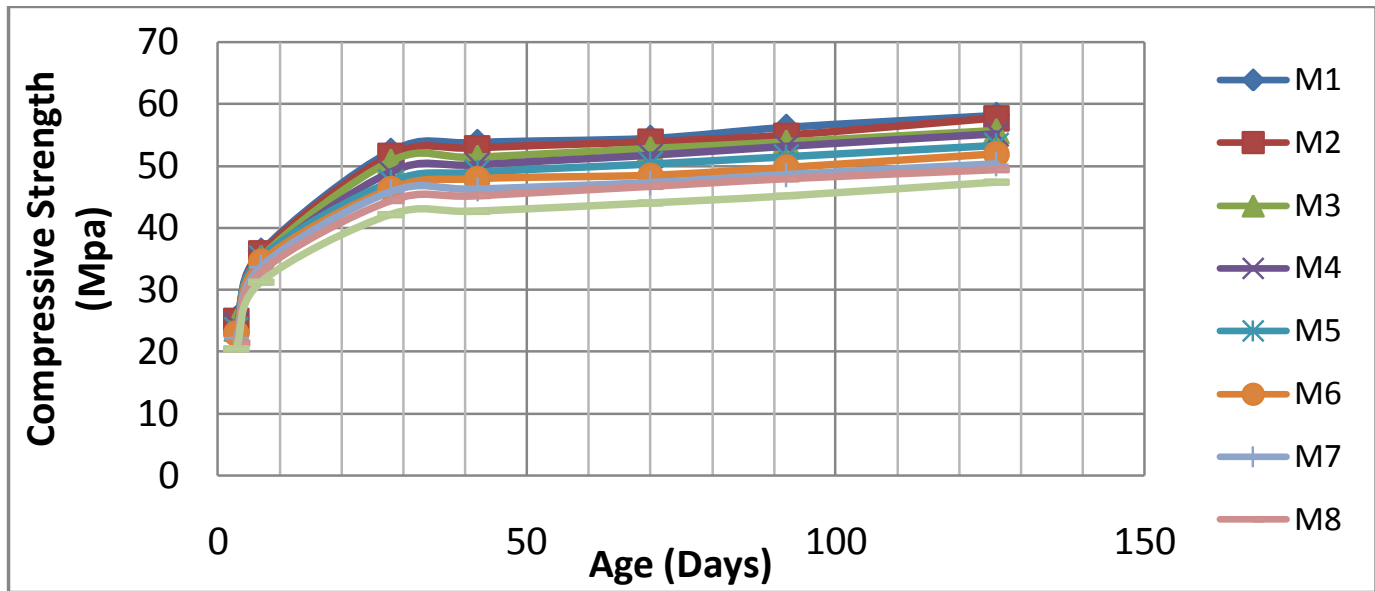

Table 10 percentage compressive strength of pond as incorporated cement

w. r. t. OPC

\begin{tabular}{|l|l|l|l|l|l|l|l|l|}
\hline \multirow{2}{*}{ Mix } & \multirow{2}{*}{ \% P.A. } & \multicolumn{6}{|l|}{ Percentage compressive strength } \\
\cline { 3 - 9 } & & 3 Days & 7 Days & 28 Days & 42 Days & 70 Days & 92 Days & 126 Days \\
\hline M1 & 2.5 & 93.889 & 97.919 & 98.755 & 97.745 & 95.491 & 96.914 & 98.525 \\
\hline M2 & 5.0 & 92.704 & 96.946 & 97.453 & 96.127 & 94.509 & 94.707 & 97.780 \\
\hline M3 & 7.5 & 92.074 & 95.216 & 95.774 & 93.400 & 92.596 & 92.810 & 94.373 \\
\hline M4 & 10.0 & 90.481 & 93.703 & 92.415 & 91.145 & 90.649 & 91.569 & 93.441 \\
\hline M5 & 12.5 & 87.667 & 94.946 & 89.377 & 88.964 & 88.193 & 88.707 & 90.288 \\
\hline M6 & 15.0 & 84.926 & 93.189 & 87.264 & 87.036 & 84.947 & 85.638 & 87.915 \\
\hline M7 & 17.5 & 81.904 & 91.000 & 86.358 & 84.000 & 82.877 & 83.690 & 85.186 \\
\hline M8 & 20.0 & 79.074 & 88.595 & 83.623 & 82.036 & 81.825 & 82.534 & 83.627 \\
\hline M9 & 22.5 & 75.741 & 84.351 & 79.509 & 77.582 & 77.193 & 77.810 & 80.254 \\
\hline
\end{tabular}

IV. Conclusions

The results of the basic study to utilize pond ash as cement replacement and change in engineering properties of cement containing pond ash are as under.

1) Pond ash should be utilized by identifying its qualities which greatly depends on the particle sizes.

2) From the examination on pond ash used for cement replacement it can be inferred that the normal consistency of cement defer according to the percentage pond ash.

3) From the examination on the pond ash incorporated cement, it can be inferred that the pond ash acts as retarder \& increases the initial setting time of the cement paste.

4) It is observed from the analysis of the compressive strength results that as the pond ash percentage increases in the cement paste the compressive strength decreases due to low pozzolanic property of the pond ash.

\section{Reference}

[1] Bera, Ghosh \& Ghosh (2007), "Compaction Characteristics of Pond Ash", Journal - Materials in Civil Engineering, Volume IXX, Issue-4, April-2007, pp-349-357.

[2] Cheriaf M., Cavalcante Rocha, J., Pérab, J. (1999). Pozzolanic properties of pulverized coal combustion bottom ash. Cement and Concrete Research, 29, 1387-1391.

[3] IS 4031 -Testing of Cement.

[4] Halstead, W.J. (1986). Use of fly ash in concrete. Washington, DC: Transportation Research Board.

[5] Jaturapitakkul, C., Cheerarot, R. (2003). Development of bottom ash as pozzolanic material. Journal of Materials in Civil Engineering, 15, 48-53.

[6] Lee, S. H., Hong J. K., Sakai, E., Daimon, M. (2003). Effect of particle size distribution of fly ash-cement system on the fluidity of cement pastes. Cement and Concrete Research , 33, 763-768.

[7] Mangaraj \& Krishnamoorthy (1994), "Use of Ponded Flyash as part Replacement of fine Aggregate in Mortar and Concrete", The Indian Concrete Journal, May-1994, pp-279-282.

[8] Ritwik, Singh \& Das (2001), "Effect of Addition of Pond Ash and Fly ash on properties of Ash-Clay Burnt Bricks", Journal - Waste Management \& Research, ISSN 0734-242X, 2007: 25 : pp- 566-571. 